\title{
Complete genome sequence of Staphylothermus hellenicus $\mathrm{PB}^{\mathrm{T}}$
}

\author{
Iain Anderson, ${ }^{1 *}$ Reinhard Wirth, ${ }^{2}$ Susan Lucas, ${ }^{1}$ Alex Copeland, ${ }^{1}$ Alla Lapidus, ${ }^{1}$ Jan-Fang \\ Cheng, ${ }^{1}$ Lynne Goodwin, ${ }^{1,3}$ Samuel Pitluck, ${ }^{1}$ Karen Davenport, ${ }^{1,3}$ John C. Detter, ${ }^{1,3}$ Cliff \\ Han, ${ }^{1,3}$ Roxanne Tapia, ${ }^{1,3}$ Miriam Land ${ }^{4}$ Loren Hauser, ${ }^{4}$ Amrita Pati, ${ }^{1}$ Natalia Mikhailova, ${ }^{1}$ \\ Tanja Woyke, ${ }^{1}$ Hans-Peter Klenk, ${ }^{5}$ Nikos Kyrpides, ${ }^{1}$ and Natalia Ivanova ${ }^{1}$ \\ ${ }^{1}$ DOE Joint Genome Institute, Walnut Creek, California, USA \\ ${ }^{2}$ University of Regensburg, Microbiology - Archaeenzentrum, Regensburg, Germany \\ ${ }^{3}$ Los Alamos National Laboratory, Los Alamos, New Mexico, USA \\ ${ }^{4}$ Biosciences Division, Oak Ridge National Laboratory, Oak Ridge, Tennessee, USA \\ ${ }^{5}$ DSMZ - German Collection of Microorganisms and Cell Cultures GmbH, Braunschweig, \\ Germany
}

*Corresponding author: IJAnderson@lbl.gov

Keywords: Archaea, Crenarchaeota, Desulfurococcaceae, hyperthermophile, hydrothermal vent, anaerobe

Staphylothermus hellenicus belongs to the order Desulfurococcales within the archaeal phylum Crenarchaeota. Strain $\mathrm{P}^{\top}$ is the type strain of the species and was isolated from a shallow hydrothermal vent system at Palaeochori Bay, Milos, Greece. It is a hyperthermophilic, anaerobic heterotroph. Here we describe the features of this organism together with the complete genome sequence and annotation. The 1,580,347 bp genome with its 1,668 proteincoding and 48 RNA genes was sequenced as part of a DOE Joint Genome Institute (JGI) Laboratory Sequencing Program (LSP) project.

\section{Introduction}

Strain P8 ${ }^{\mathrm{T}}$ (=DSM $12710=$ JCM 10830) is the type strain of the species Staphylothermus hellenicus. It was isolated from a shallow hydrothermal vent at Palaeochori Bay near the island of Milos, Greece [1]. There is one other validly named species in the genus, $S$. marinus, for which a complete genome sequence has been determined and published $[2,3]$. The $S$. hellenicus genome is the ninth to be published from the order Desulfurococcales in the phylum Crenarchaeota. The only other genus in the Desulfurococcales for which two species have been sequenced is Desulfurococcus. Figure 1 shows the phylogenetic position of $S$. hellenicus with respect to the other species in the order Desulfurococcales.

\section{Organism information}

$S$. hellenicus was isolated from sediment at Palaeochori Bay, Milos, Greece [1]. For isolation, 1 $\mathrm{ml}$ of sediment was added to half-strength SME medium [11] with $2 \%$ elemental sulfur and incubated at $90^{\circ} \mathrm{C}$ under $\mathrm{H}_{2} / \mathrm{CO}_{2}$. Colonies were isolated on plates with the same medium and with $1 \%$ Phytagel and $2-3 \%$ sodium alginate added [1]. S. hellenicus is a regular-shaped coccus (Figure 2) which can form large aggregates of up to fifty cells, similar to $S$. marinus $[1,12]$. No flagella were observed and cells were nonmotile. The temperature range for growth of $S$. hellenicus is $70-90^{\circ} \mathrm{C}$, with an optimum at $85^{\circ} \mathrm{C}$ [1]. The salinity range was from $2 \%$ to $8 \% \mathrm{NaCl}$, and the optimum was $4 \% \mathrm{NaCl}$ [1]. The $\mathrm{pH}$ range for growth was from 4.5 to 7.5 . The optimum $\mathrm{pH}$ was 6.0 [1]. S. hellenicus is a strict anaerobe, and can grow under $\mathrm{H}_{2} / \mathrm{CO}_{2}$ or $\mathrm{N}_{2} / \mathrm{CO}_{2}$ [1]. It is a heterotroph which grows well on yeast extract but poorly on peptone [1]. Many carbon sources were tested, but no growth was observed, showing that a complex nutrient source is required [1]. Elemental sulfur was required for growth [1]. The features of the organism are listed in Table 1. 


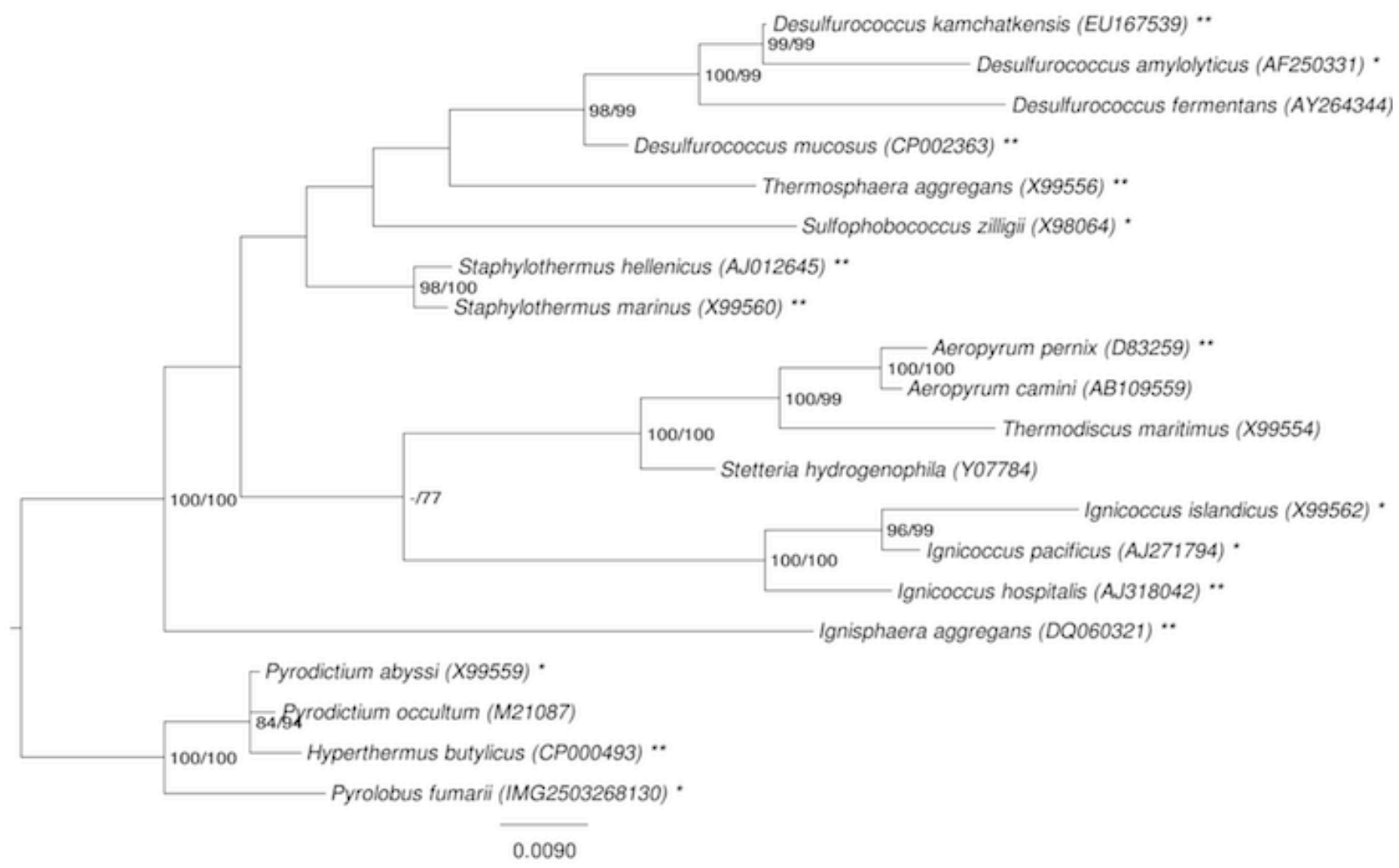

Figure 1. Phylogenetic tree highlighting the position of $S$. hellenicus relative to the type strains of the other species within the order Desulfurococcales. The tree was inferred from 1,333 aligned characters [4,5] of the 16S rRNA gene sequence under the maximum likelihood $(\mathrm{ML})$ criterion [6]. Rooting was done initially using the midpoint method [7] and then checked for its agreement with the current classification (Table 1). The branches are scaled in terms of the expected number of substitutions per site. Numbers adjacent to the branches are support values from 1,000 ML bootstrap replicates [8] (left) and from 1,000 maximum parsimony bootstrap replicates [9] (right) if larger than $60 \%$. Lineages with type strain genome sequencing projects registered in GOLD [10] are labeled with one asterisk, those listed as 'Complete and Published' with two asterisks.

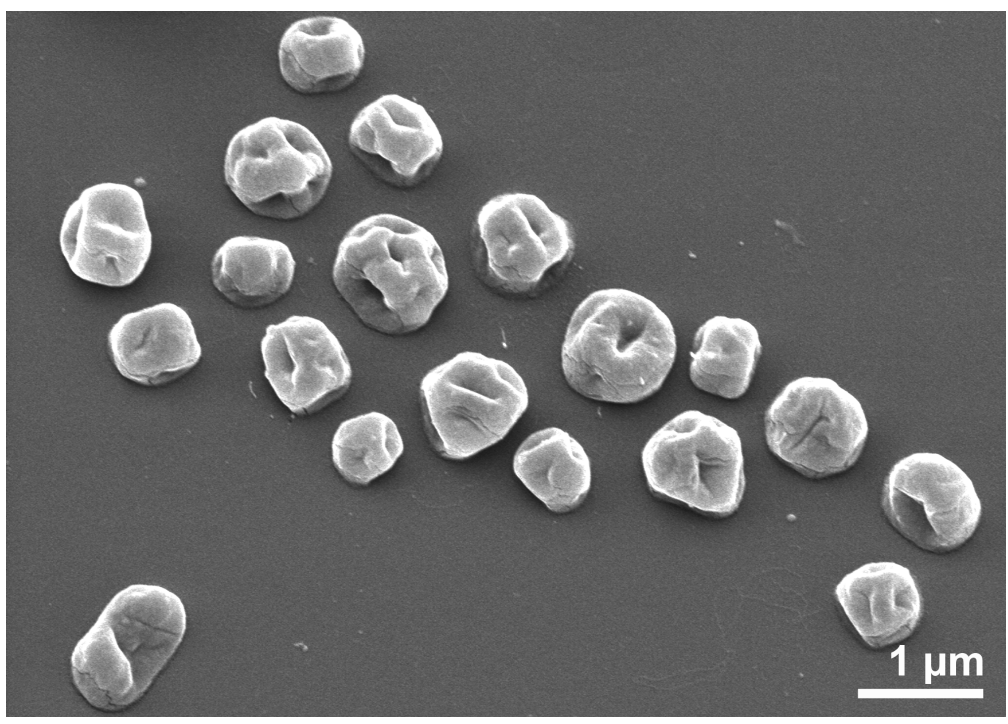

Figure 2. Scanning electron micrograph of $S$. hellenicus $\mathrm{P} 8^{\top}$. 
Table 1. Classification and general features of $S$. hellenicus $P 8^{\top}$ according to the MIGS recommendations [13]

\begin{tabular}{|c|c|c|c|}
\hline MIGS ID & Property & Term & Evidence code $^{\mathrm{a}}$ \\
\hline & \multirow{8}{*}{ Current classification } & Domain Archaea & TAS [14] \\
\hline & & Phylum Crenarchaeota & TAS $[15,16]$ \\
\hline & & Class Thermoprotei & TAS $[16,17]$ \\
\hline & & Order Desulfurococcales & TAS $[16,18]$ \\
\hline & & Family Desulfurococcaceae & TAS [19-21] \\
\hline & & Genus Staphylothermus & TAS $[12,22]$ \\
\hline & & Species Staphylothermus hellenicus & TAS [1] \\
\hline & & Type strain P8 & TAS [1] \\
\hline & Cell shape & coccus & TAS [1] \\
\hline & Motility & nonmotile & TAS [1] \\
\hline & Sporulation & nonsporulating & NAS \\
\hline & Temperature range & $70-90^{\circ} \mathrm{C}$ & TAS [1] \\
\hline & Optimum temperature & $85^{\circ} \mathrm{C}$ & TAS [1] \\
\hline MIGS-6.3 & Salinity & $2-8 \% \mathrm{NaCl}$ (optimum 4\%) & TAS [1] \\
\hline \multirow[t]{3}{*}{ MIGS-22 } & Oxygen requirement & anaerobe & TAS [1] \\
\hline & Carbon source & yeast extract & TAS [1] \\
\hline & Energy metabolism & heterotrophic & TAS [1] \\
\hline MIGS-6 & Habitat & marine geothemally heated areas & TAS [1] \\
\hline MIGS-15 & Biotic relationship & free-living & TAS [1] \\
\hline \multirow[t]{3}{*}{ MIGS-14 } & Pathogenicity & none & NAS \\
\hline & Biosafety level & 1 & NAS \\
\hline & Isolation & geothermally heated sediment & TAS [1] \\
\hline MIGS-4 & Geographic location & Palaeochori Bay, Milos, Greece & TAS [1] \\
\hline MIGS-5 & Isolation time & September 1996 & TAS [1] \\
\hline $\begin{array}{l}\text { MIGS-4.1 } \\
\text { MIGS-4.2 }\end{array}$ & $\begin{array}{l}\text { Latitude } \\
\text { longitude }\end{array}$ & $\begin{array}{l}36.674 \\
24.517\end{array}$ & TAS [1] \\
\hline MIGS-4.3 & Depth & $4-10 m$ & TAS [1] \\
\hline MIGS-4.4 & Altitude & not applicable & \\
\hline
\end{tabular}

a) Evidence codes - IDA: Inferred from Direct Assay; TAS: Traceable Author Statement (i.e., a direct report exists in the literature); NAS: Non-traceable Author Statement (i.e., not directly observed for the living, isolated sample, but based on a generally accepted property for the species, or anecdotal evidence). These evidence codes are from the Gene Ontology project [23].

\section{Genome sequencing information Genome project history}

This organism was selected for sequencing on the basis of its phylogenetic position and is part of a Laboratory Sequencing Project (LSP) to sequence diverse archaea. The genome project is listed in the Genomes On Line Database [10] and the complete genome sequence has been deposited in GenBank. Sequencing, finishing, and annotation were performed by the DOE Joint Genome Institute (JGI). A summary of the project information is shown in Table 2. 
Table 2. Genome sequencing project information

\begin{tabular}{lll}
\hline MIGS ID & Property & Term \\
\hline MIGS-31 & Finishing quality & Finished \\
Illumina standard library, 454 standard library, \\
MIGS-29 & Libraries used & 45428 kb paired end library \\
MIGS-31.2 & Sequencing platforms & Illumina GA II, 454 GS FLX Titanium \\
MIGS-30 & Assemblers & $462 \times$ with Illumina, 132× with 454 \\
MIGS-32 & Gene calling method & Prodigal, GenePRIMP \\
& INSDC ID & CP002051 \\
& Genbank Date of Release & June 1, 2010 \\
& GOLD ID & Gc01350 \\
& NCBI project ID & 33683 \\
& Source material identifier & DSM 12710 \\
& Project relevance & Phylogenetic diversity, biotechnology \\
\hline
\end{tabular}

\section{Growth conditions and DNA isolation}

$S$. hellenicus $\mathrm{P}^{\mathrm{T}}$ cells were grown in a 300 liter fermenter at $85^{\circ} \mathrm{C}$ in SME medium [11] with $0.1 \%$ yeast extract, $0.1 \%$ peptone, and $0.7 \%$ elemental sulfur under a $200 \mathrm{kPa} \mathrm{N} 2$ atmosphere. DNA was isolated with a Qiagen Genomic 500 DNA Kit.

\section{Genome sequencing and assembly}

The genome of $S$. hellenicus was sequenced at the Joint Genome Institute (JGI) using a combination of Illumina and 454 technologies. An Illumina GA II shotgun library with reads of $730 \mathrm{Mb}$, a $454 \mathrm{Ti}-$ tanium draft library with average read length of $310.5+/-187.8$ bases, and a paired end 454 library with an average insert size of $28 \mathrm{~Kb}$ were generated for this genome. Illumina sequencing data was assembled with Velvet [24], and the consensus sequences were shredded into $1.5 \mathrm{~kb}$ overlapped fake reads and assembled together with the 454 data with Newbler. Draft assemblies were based on $208 \mathrm{Mb} 454$ draft data.

The initial Newbler assembly contained 4 contigs in 1 scaffold. We converted the initial 454 assembly into a phrap assembly by making fake reads from the consensus, collecting the read pairs in the 454 paired end library. The Phred/Phrap/Consed software package was used for sequence assembly and quality assessment [25-27] in the following finishing process. After the shotgun stage, reads were assembled with parallel phrap (High Performance
Software, LLC). Possible mis-assemblies were corrected with gapResolution (Cliff Han, unpublished), Dupfinisher [28], or sequencing cloned bridging PCR fragments with subcloning or transposon bombing (Epicentre Biotechnologies, Madison, WI). Gaps between contigs were closed by editing in Consed, by PCR and by Bubble PCR primer walks. A total of 23 additional reactions were necessary to close gaps and to raise the quality of the finished sequence.

\section{Genome annotation}

Genes were identified using Prodigal [29], followed by a round of manual curation using GenePRIMP [30]. The predicted CDSs were translated and used to search the National Center for Biotechnology Information (NCBI) nonredundant database, UniProt, TIGRFam, Pfam, PRIAM, KEGG, COG, and InterPro databases. The tRNAScan-SE tool [31] was used to find tRNA genes, whereas ribosomal RNAs were found by using BLASTn against the ribosomal RNA databases. The RNA components of the protein secretion complex and the RNase P were identified by searching the genome for the corresponding Rfam profiles using INFERNAL [32]. Additional gene prediction analysis and manual functional annotation was performed within the Integrated $\mathrm{Mi}$ crobial Genomes (IMG) platform [33] developed by the Joint Genome Institute, Walnut Creek, CA, USA [34]. 


\section{Genome properties}

The genome includes one chromosome and no plasmids, for a total size of 1,580,437 bp (Table 3 and Figure 3). This genome size is close to the average for Desulfurococcales. The GC percentage is $36.8 \%$, which is lower than most of the Desulfurococcales. A total of 1,716 genes were identified: 48
RNA genes and 1,668 protein-coding genes. There are 69 pseudogenes, comprising $4.1 \%$ of the protein-coding genes. About $62 \%$ of predicted genes begin with ATG, 30\% begin with TTG, and $7 \%$ begin with GTG. There is one copy of each ribosomal RNA. Table 4 shows the distribution of genes in COG categories.

Table 3. Nucleotide content and gene count levels of the genome

\begin{tabular}{lrr}
\hline Attribute & Value & \% of total $^{\mathbf{a}}$ \\
\hline Size (bp) & $1,580,437$ & $100.0 \%$ \\
G+C content (bp) & 582,173 & $36.8 \%$ \\
Coding region (bp) & $1,383,053$ & $87.5 \%$ \\
Number of replicons & 1 & \\
Extrachromosomal elements & 0 & \\
Total genes & 1,716 & \\
RNA genes & 48 & \\
rRNA operons & 1 & \\
Protein-coding genes & 1,668 & $100.0 \%$ \\
Pseudogenes & 69 & $4.1 \%$ \\
Genes with function prediction & 975 & $58.5 \%$ \\
Genes in paralog clusters & 98 & $5.9 \%$ \\
Genes assigned to COGs & 1,093 & $65.5 \%$ \\
Genes assigned Pfam domains & 1,135 & $68.0 \%$ \\
Genes with signal peptides & 129 & $7.7 \%$ \\
Genes with transmembrane helices & 342 & $20.5 \%$ \\
CRISPR repeats & 3 & $\%$ of total \\
\hline
\end{tabular}

a) The total is based on either the size of the genome in base pairs or the total number of protein coding genes in the annotated genome

\section{Comparison with the $S$. marinus genome}

The genome of $S$. hellenicus is slightly larger than the genome of $S$. marinus (1.58 Mbp vs. $1.57 \mathrm{Mbp}$ ), and the number of protein-coding genes is also larger (1668 vs. 1610). However, the number of pseudogenes is also higher in $S$. hellenicus (69 vs. 40). Some of the COG categories show different numbers of genes between the two organisms. $S$. hellenicus has 25 additional genes that do not belong to COGs. S. hellenicus has greater numbers of genes involved in cell wall biogenesis (39 vs. 23), nucleotide transport and metabolism (44 vs. 39) and carbohydrate transport and metabolism (79 vs. 72 ), while $S$. marinus has greater numbers of genes in the categories of energy production and conversion (92 vs. 79) and inorganic ion transport and metabolism (85 vs. 67).

The genes involved in cell wall metabolism that are in $S$. hellenicus but not in $S$. marinus are genes involved in nucleotide-sugar metabolism and glycosyltransferases, suggesting that $S$. hellenicus may have a greater variety of sugars attached to glycolipids and glycoproteins. Most of the additional $S$. hellenicus genes are located within a region of fifty genes on the chromosome (Shell_0865-Shell_0915) that is not present in $S$. marinus. The additional genes in $S$. hellenicus involved in nucleotide metabolism include adenylosuccinate synthase, adenylosuccinate lyase, and GMP synthase. Both $S$. hellenicus and $S$. marinus lack de novo purine synthesis, but the presence of these three additional enzymes suggests that $S$. hellenicus may be able to synthesize AMP and GMP from IMP, while $S$. marinus is unable to do so. The additional genes in carbohydrate transport and metabolism include nucleotide-sugar modifying enzymes that were also included in cell wall metabolism, but they also include a probable $\beta$-1,4-endoglucanase (cellulase) from glycosyl hydrolase family 5 .

The genes found in S. marinus but not in S. hellenicus belong to the categories of energy production 
and conversion, and inorganic ion transport and metabolism. They include proteins related to subunits of multisubunit cation:proton antiporters and proteins related to subunits of NADH dehydrogenase and formate hydrogen lyase. These proteins are similar to subunits of mbh, a multisubunit membrane-bound hydrogenase from Pyrococcus furiosus [35], and mbx, a multisubunit complex of unknown function that probably has a role in sulfur reduction, also from $P$. furiosus [36]. S. marinus has three operons related to $\mathrm{mbh}$ and $\mathrm{mbx}$, while $S$. hellenicus has only one, suggesting that the three operons may be redundant in function in $S$. marinus. Since $S$. marinus and $S$. hellenicus lack other enzymes involved in sulfur reduction, it is possible that these $\mathrm{mbh} / \mathrm{mbx}$-related operons play a role in sulfur reduction in these organisms.

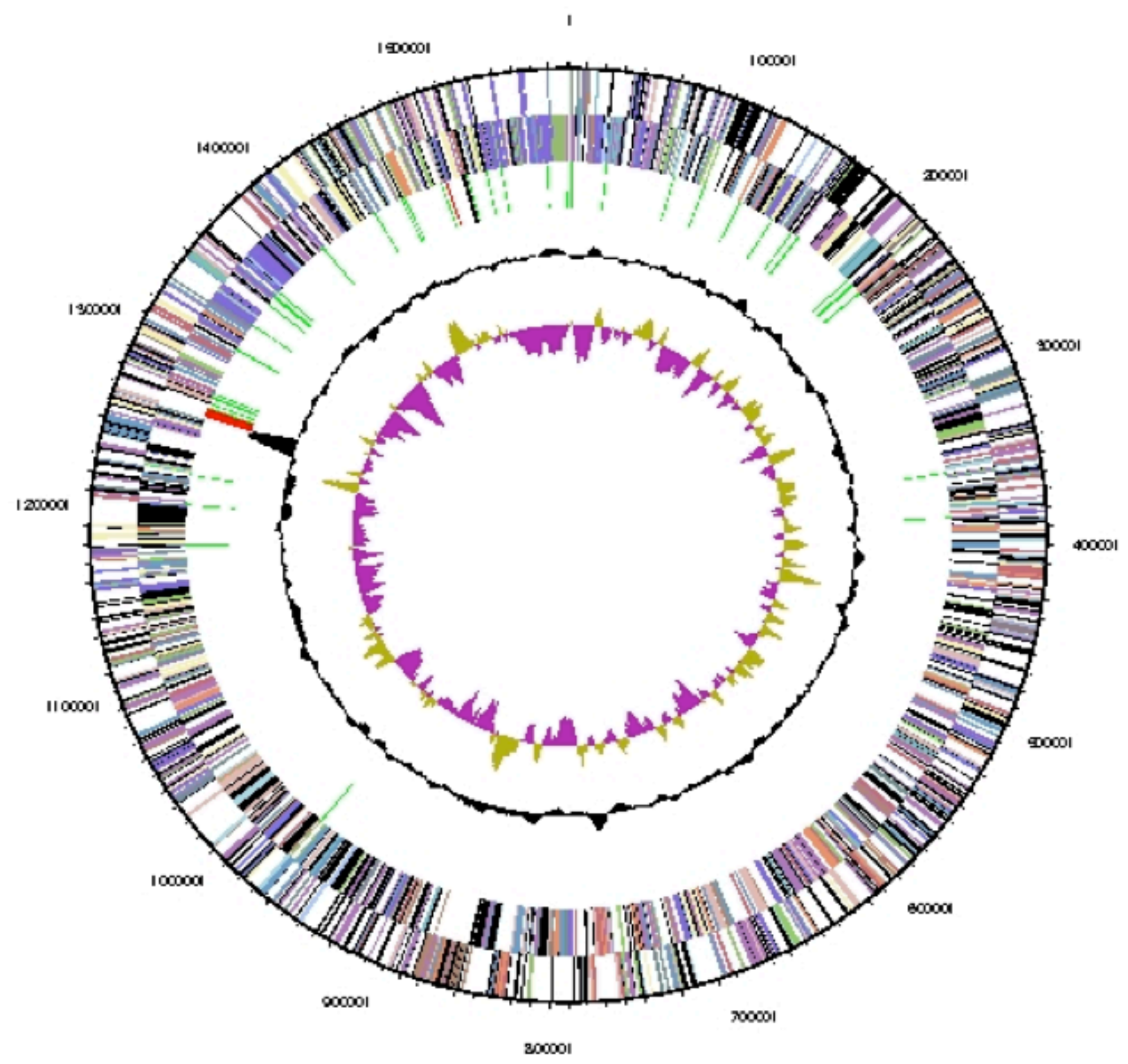

Figure 3. Graphical circular map of the chromosome. From outside to the center: Genes on forward strand (colored by COG categories), genes on reverse strand (colored by COG categories), RNA genes (tRNAs green, rRNAs red, other RNAs black), GC content, and GC skew. 
Table 4. Number of genes associated with the 25 general COG functional categories

\begin{tabular}{cccl}
\hline Code & Value & \%age $^{\text {a }}$ & Description \\
\hline J & 161 & 9.7 & Translation \\
A & 2 & 0.1 & RNA processing and modification \\
K & 59 & 3.5 & Transcription \\
L & 72 & 4.3 & Replication, recombination and repair \\
B & 2 & 0.1 & Chromatin structure and dynamics \\
D & 7 & 0.4 & Cell cycle control, mitosis and meiosis \\
Y & 0 & 0.0 & Nuclear structure \\
V & 18 & 1.1 & Defense mechanisms \\
T & 20 & 1.2 & Signal transduction mechanisms \\
M & 39 & 2.3 & Cell wall/membrane biogenesis \\
N & 4 & 0.2 & Cell motility \\
Z & 0 & 0.0 & Cytoskeleton \\
W & 0 & 0.0 & Extracellular structures \\
U & 11 & 0.7 & Intracellular trafficking and secretion \\
O & 49 & 2.9 & Posttranslational modification, protein turnover, chaperones \\
C & 79 & 4.7 & Energy production and conversion \\
G & 79 & 4.7 & Carbohydrate transport and metabolism \\
E & 73 & 4.4 & Amino acid transport and metabolism \\
F & 44 & 2.6 & Nucleotide transport and metabolism \\
H & 53 & 3.2 & Coenzyme transport and metabolism \\
I & 15 & 0.9 & Lipid transport and metabolism \\
P & 67 & 4.0 & Inorganic ion transport and metabolism \\
Q & 5 & 0.3 & Secondary metabolites biosynthesis, transport and catabolism \\
R & 194 & 11.6 & General function prediction only \\
S & 116 & 7.0 & Function unknown \\
- & 575 & 34.5 & Not in COGs \\
\hline
\end{tabular}

a) The total is based on the total number of protein coding genes in the annotated genome.

\section{References}

1. Arab H, Völker H, Thomm M. Thermococcus aegaeicus sp. nov. and Staphylothermus hellenicus sp. nov., two novel hyperthermophilic archaea isolated from geothermally heated vents off Palaeochori Bay, Milos, Greece. Int J Syst Evol Microbiol 2000; 50:2101-2108. PubMed doi:10.1099/00207713-50-6-2101

2. Anderson IJ, Dharmarajan L, Rodriguez J, Hooper S, Porat I, Ulrich LE, Elkins JG, Mavromatis K, Sun $\mathrm{H}$, Land $\mathrm{M}$, et al. The complete genome sequence of Staphylothermus marinus reveals differences in sulfur metabolism among heterotrophic Crenarchaeota. BMC Genomics 2009; 10:145. PubMed doi:10.1186/1471-2164-10-145

3. Anderson IJ, Sun H, Lapidus A, Copeland A, Glavina Del Rio T, Tice H, Dalin E, Lucas S, Barry K, Land $M$, et al. Complete genome sequence of Staphylothermus marinus Stetter and Fiala 1986 type strain F1. Stand Genomic Sci 2009; 1:183188. PubMed doi:10.4056/sigs.30527 
Anderson et al.

4. Castresana J. Selection of conserved blocks from multiple alignments for their use in phylogenetic analysis. Mol Biol Evol 2000; 17:540-552. PubMed

5. Lee C, Grasso C, Sharlow MF. Multiple sequence alignment using partial order graphs. Bioinformatics 2002; 18:452-464. PubMed

doi:10.1093/bioinformatics/18.3.452

6. Stamatakis A, Hoover P, Rougemont J. A rapid bootstrap algorithm for the RAxML web servers. Syst Biol 2008; 57:758-771. PubMed doi:10.1080/10635150802429642

7. Hess PN, De Moraes Russo CA. An empirical test of the midpoint rooting method. Biol / Linn SoC Lond 2007; 92:669-674. doi:10.1111/j.1095$\underline{8312.2007 .00864 . x}$

8. Pattengale ND, Alipour M, Bininda-Emonds ORP, Moret BME, Stamatakis A. How many bootstrap replicates are necessary? I Comput Biol 2010; 17:337-354. PubMed doi:10.1089/cmb.2009.0179

9. Swofford DL. PAUP*: Phylogenetic analysis using parsimony (*and other methods), Version 4.0 b10. Sinauer Associates, Sunderland, 2002.

10. Liolios K, Chen IM, Mavromatis K, Tavernarakis $\mathrm{N}$, Hugenholtz P, Markowitz VM, Kyrpides NC. The Genomes On Line Database (GOLD) in 2009: status of genomic and metagenomic projects and their associated metadata. Nucleic Acids Res 2010; 38:D346-D354. PubMed doi:10.1093/nar/gkp848

11. Stetter KO, König H, Stackebrandt E. Pyrodictium gen. nov., a new genus of submarine disc-shaped sulfur reducing archaebacteria growing optimally at $105^{\circ} \mathrm{C}$. Syst Appl Microbiol 1983; 4:535-551.

12. Fiala G, Stetter KO, Jannasch HW, Langworthy TA, Madon J. Staphylothermus marinus sp. nov. represents a novel genus of extremely thermophilic submarine heterotrophic archaebacteria growing up to $98^{\circ} \mathrm{C}$. Syst Appl Microbiol 1986; 8:106113.

13. Field D, Garrity G, Gray T, Morrison N, Selengut J, Sterk P, Tatusova T, Thomson N, Allen MJ, Angiuoli SV, et al. The minimum information about a genome sequence (MIGS) specification. Nat Biotechnol 2008; 26:541-547. PubMed doi:10.1038/nbt1360

14. Woese CR, Kandler O, Wheelis ML. Towards a natural system of organisms: proposal for the domains Archaea, Bacteria, and Eucarya. Proc Natl
Acad Sci USA 1990; 87:4576-4579. PubMed doi:10.1073/pnas.87.12.4576

15. Garrity GM, Holt JG. Phylum AI. Crenarchaeota phy. nov. In Bergey's Manual of Systematic Bacteriology, vol. 1. $2^{\text {nd }}$ ed. Edited by: Garrity GM, Boone DR and Castenholz RW. Springer, New York 2001: 169-210.

16. List Editor. Validation of publication of new names and new combinations previously effectively published outside the IJSEM. Validation List no. 85. Int J Syst Evol Microbiol 2002; 52:685690. PubMed doi:10.1099/ijs.0.02358-0

17. Reysenbach AL. Class I. Thermoprotei class. nov. In Bergey's Manual of Systematic Bacteriology, vol. 1. $2^{\text {nd }}$ ed. Edited by: Garrity GM, Boone DR, and Castenholz RW. Springer, New York; 2001: 169.

18. Huber H, Stetter O. Order II. Desulfurococcales ord. nov. In: Garrity GM, Boone DR, Castenholz RW (eds), Bergey's Manual of Systematic Bacteriology, Second Edition, Volume 1, Springer, New York, 2001, p. 179-180.

19. Burggraf S, Huber H, Stetter KO. Reclassification of the crenarchael orders and families in accordance with $16 \mathrm{~S}$ rRNA sequence data. Int I Syst Bacteriol 1997; 47:657-660. PubMed doi:10.1099/00207713-47-3-657

20. Zillig W, Stetter KO, Prangishvilli D, Schäfer W, Wunderl S, Janekovic D, Holz I, Palm P. Desulfurococcaceae, the second family of the extremely thermophilic, anaerobic, sulfur-respiring Thermoproteales. Zentralbl Bakteriol Parasitenkd Infektioskr Hyg Abt 1 Orig 1982; 3:304-317.

21. List Editor. Validation List no. 10. Validation of the publication of new names and new combinations previously effectively published outside the IJSB. Int J Syst Bacteriol 1983; 33:438-440. doi:10.1099/00207713-33-2-438

22. List Editor. Validation List no. 22. Validation of the publication of new names and new combinations previously effectively published outside the IJSB. Int J Syst Bacteriol 1986; 36:573-576. doi:10.1099/00207713-36-4-573

23. Ashburner M, Ball CA, Blake JA, Botstein D, Butler H, Cherry JM, Davis AP, Dolinski K, Dwight SS, Eppig JT, et al. Gene ontology: tool for the unification of biology. The Gene Ontology Consortium. Nat Genet 2000; 25:25-29. PubMed doi:10.1038/75556

24. Zerbino DR, Birney E. Velvet: algorithms for de novo short read assembly using de Bruijn graphs. 
Genome Res 2008; 18:821-829. PubMed doi:10.1101/gr.074492.107

25. Ewing B, Green P. Base-calling of automated sequencer traces using phred. II. Error probablilities. Genome Res 1998; 8:186-194. PubMed

26. Ewing B, Hillier L, Wendl MC, Green P. Basecalling of automated sequencer traces using phred. I. Accuracy assessment. Genome Res 1998; 8:175-185. PubMed

27. Gordon D, Abajian C, Green P. Consed: a graphical tool for sequence finishing. Genome Res 1998; 8:195-202. PubMed

28. Han C, Chain P. Finishing repeat regions automatically with Dupfinisher. In Proceedings of the 2006 international conference on bioinformatics and computational biology, ed. Arabnia HR, Valafar H. CSREA Press, 2006:141-146.

29. Hyatt D, Chen GL, Lacascio PF, Land ML, Larimer FW, Hauser LJ. Prodigal: prokaryotic gene recognition and translation initiation site identification. BMC Bioinformatics 2010; 11:119. PubMed doi:10.1186/1471-2105-11-119

30. Pati A, Ivanova NN, Mikhailova N, Ovchinnikova G, Hooper SD, Lykidis A, Kyrpides NC. GenePRIMP: a gene prediction improvement pipeline for prokaryotic genomes. Nat Methods 2010; 7:455-457. PubMed doi:10.1038/nmeth.1457
31. Lowe TM, Eddy SR. tRNAscan-SE: a program for improved detection of transfer RNA genes in genomic sequence. Nucleic Acids Res 1997; 25:955-964. PubMed doi:10.1093/nar/25.5.955

32. INFERNAL. Inference of RNA alignments. http://infernal.janelia.org

33. The Integrated Microbial Genomes (IMG) platform. http://img.jgi.doe.gov

34. Markowitz VM, Mavromatis K, Ivanova NN, Chen IMA, Chu K, Kyrpides NC. IMG ER: a system for microbial genome annotation expert review and curation. Bioinformatics 2009; 25:2271-2278. PubMed doi:10.1093/bioinformatics/btp393

35. Silva PJ, van den Ban EC, Wassink $\mathrm{H}$, Haaker $\mathrm{H}$, de Castro B, Robb FT, Hagen WR. Enzymes of hydrogen metabolism in Pyrococcus furiosus. Eur J Biochem 2000; 267:6541-6551. PubMed doi:10.1046/j.1432-1327.2000.01745.x

36. Schut GJ, Bridger SL, Adams MWW. Insights into the metabolism of elemental sulfur by the hyperthermophilic archaeon Pyrococcus furiosus: characterization of a coenzyme A-dependent NAD(P)H sulfur oxidoreductase. J Bacteriol 2007; 189:4431-4441. PubMed doi:10.1128//B.00031$\underline{07}$ 